\title{
Bicultural Literacy Curriculum
}

\author{
Yer J. Thao \\ Department of Curriculum and Instruction, Graduate School of Education, Portland State University, \\ Portland, USA \\ Email: thaoy@pdx.edu
}

Received August 24 $4^{\text {th }}$, 2011; revised October $4^{\text {th }}, 2011$; accepted October $30^{\text {th }}, 2011$

\begin{abstract}
This article examines the literacy issues in public school in the United States, and points out that current programs do not have a meaningful cultural connection to bicultural and bilingual students. The findings indicate that literacy must become part of bicultural and bilingual students' reality in order to empower them. The pedagogical content of literacy must acknowledge bicultural and bilingual students' culture so they can make connections to learning literacy. In order to help bicultural and bilingual students acquire the necessary academic skills to succeed on high-stakes tests that are demanded by No Child Left Behind Law, public schools need to infuse home culture literacy as part of literacy programs and practices.
\end{abstract}

Keywords: Language Education; Multicultural Education; Cultural Literacy; Literacy Empowerment; Bicultural and Bilingual Education

Literacy becomes a meaningful construct to the degree that it is viewed as a set of practices that functions to either power or disempower people (Freire \& Macedo, 1987: p. 141).

Literacy has a very important role in the public school-to give power to bicultural and bilingual students, so they can maintain a sense of cultural, language, and identity balance between their home culture and the dominant culture. Bicultural and bilingual students have struggled to make a connection through public school literacy programs that have been washed to remove cultural identity. Increasingly, bicultural and bilingual students are being labeled as illiterate and tracked into lower level academic classes. Often they are placed into remedial English reading and writing for their language arts class. Due to these students being tracked into other low academic classes they are not prepared for college, which would give them an opportunity to succeed in life. In addition, bicultural and bilingual students face discrimination when they try to enter college and/or to get employment. Colleges and employers use academic records to determine who will be accepted. Therefore, they view bicultural and bilingual students as lacking the academic skills to perform in college or to fulfill their employment responsibilities in reading and written communication. Darder (1991) points out that through public education bicultural students are often being blamed as lacking the necessary intelligence and they have no motivation to learn even if they were given the opportunities.

Educators need to understand that children who are learning the English language tend to have greater trouble with reading and writing English, because the types of literacy found in the public school too often have no representation of their lives as bicultural and bilingual students. Literacy programs too often do not succeed in teaching bicultural and bilingual students to think critically in academic language, which is the basic expectation for monolingual and monocultural students. Most literature in the pubic school builds on the cultural values of the Westerner, European/American middle class tradition and does not reflect the language, norms, rituals, symbols, skills, behaveiors, beliefs, and values of bicultural and bilingual students.
Critical literacy theorist Cadiero-Kaplan (2004) states, "The curriculum of cultural literacy reflects an ideology based in the Western traditions and as such attempts to control not only the spaces where knowledge is produced, but to make a certain core knowledge legitimate" (p. 8). The purpose of this article is to discuss issues in literacy in public schools in the United States, and to point out that the current programs do not make a meaningful cultural connections to bicultural and bilingual students.

Literacy in the public school's classrooms for bicultural and bilingual students is mostly geared toward an English transitional curriculum where students learn the basic skills of listening, speaking, reading, and writing in English. It does not prepare bicultural and bilingual students to move onto a higher critical thinking literacy level. English transitional curriculum lacks relevance to the students who find no cultural connection to this type of literacy. They find that it has no sense of empowerment. Bicultural and bilingual students spend a great deal of time drilling the proper English grammar rules, and reading materials to reinforce these grammar structures. This type of literacy provides bilingual and bicultural students with very little motivation in reading and writing, when the materials give them no encouragement in connecting with home culture stories. When bicultural and bilingual students do not read at the grade level standard they often are labeled as being at risk of not knowing how to read and speak properly in the English language. Therefore, they end up being placed in remedial literacy classes.

The ideology of US public school literacy has been to educate students to read and write only in English, with the notion of assimilating bicultural and bilingual students into the Western culture and tradition. For the most part public school literacy has not encouraged students to maintain their home culture and language. Instead, it continues to dismantle students' heritage and family values. The federally mandated law, No Child Left Behind Act in 2001, is a good example of the way literacy is used as a tool to build children's reading and writing skills in English but not in the students' home languages. This No Child 
Left Behind Act clearly explains that public school literacy programs should reflect only the cultural values of the EuroAmericans and drive for English only. This federal law clearly stated that if a student's reading scores fail to meet the state's benchmark 2 years in a row then this student needs to be transfer to a different school district or the reading program needs to be improve (US Department of Education, 2004). The law specifically targets only the low income and minority communities. The hidden message behind this federal law is that in order to close the achievement gap for low income and minority students, they must be forced to give up their cultural norms and social values. With this policy design, these students will be taught in the culture of schools, which mainly reflects the middle class Euro-American culture. It says to our diverse students and parents that schools have no interest invested in cross-cultural perspectives.

Public schools continue to be a more difficult learning environment for bicultural and bilingual students, and continue to disempower them. The No Child Left Behind law forces bicultural and bilingual students to divorce their heritage, family and community by requiring public schools to measure their educational outcomes with high-stakes standardized tests. Without the incorporation of students' culture and language into the reading and writing programs in the public school, bicultural and bilingual students will be singled out by high-stakes tests. Spring (2004) argues, "High-stakes standardized tests given in elementary, middle, and high schools represent only a single culture. Given to all students, test questions should not be based on knowledge known only to students in a minority culture" (pp. 122-123).

With the implementation of the No Child Left Behind law, bicultural and bilingual students will continue to be alienated and left behind through literacy education in schools that do not value the cultural knowledge that they bring from home. In her research, Olsen (1996) found that the cultural norms of public school are a cause of isolation for immigrant students in the high school campus. Therefore, if literacy in the public school continues to treat bicultural and bilingual students like foreigners and do not infuse the cultural values of these students, and then bicultural and bilingual students will continue to be marginalized in the public school system. They will be single out in the US public education without having a culture identity.

We strongly assert that public school literacy should empower bicultural and bilingual students by helping them to recognize their heritage, language, and cultural values, as well as allowing them to have voices in the schools. Powell (1999) contends that counterhegemonic language must be established in the classroom in order for students to have their voices heard. Macedo (1994) argues the same point that teachers need to encourage students to have an open dialogue and daily contacts in a language and culture with which the students are familiar. He states, "Without the cultivation of their native language, and robbed of the opportunity for reflection and critical thinking, linguistic-minority students find themselves unable to re-create their culture and history" (p. 135).

Several researchers in The Skin That We Speak, edited by Lisa Delpit and Joanne Kilgour Dowdy, pointed out the importance of Ebonics in the Oakland Unified School District, California. These researchers argue that an individual should never feel a sense of inferiority, as often imparted by teachers, when using either formal English or a dialectal language of intimacy (Delpit \& Dowdy, 2002). In the 1996 California debate about
Ebonics, the Oakland school board decided to recognize the language variety spoken by African Americans. The Linguistic Society of America Resolution on the Oakland "Ebonics" issue, written about the decision of the Oakland school board, affirms that it "is linguistically and pedagogically sound" to "recognize the vernacular of African American students in teaching them Standard English” (Delpit \& Dowdy, 2002: p. 224). This means that Oakland Unified School District uses teaching the language of literacy in Ebonics to African American students as a direct and relevant reflection of the students' cultural history. Accepting Ebonics in Oakland Unified School District create a commitment to connect culture and language of Black/African American students. Respect for the home language must always be part of the literacy curricula in the public school (Ada \& Campoy, 1998; Degado-Gaitan, 1990, 1994; Dyc, 1994; McLaughlin, 1994).

\section{My Personal Experiences with Literacy in American Public School}

Historically American public schools use literacy to encourage bicultural and bilingual students to carry on Western ideas, language, and culture. Literature in some public school's classrooms still reflect only the white European American middle class culture and its reality. Without multicultural and multilingual literacy, the school system ignores and undermines students' traditional beliefs, cultural and social values, and learning preferences. For example, public school teachers who are reluctant reexamine their teaching curriculum and materials, and have a strong belief that school will not include other cultural content but only white European middle class culture. This traditional practice causes many hardships to bilingual and bicultural students. McLaren (1998) states, "Literacy becomes a weapon that can be used against those groups who are 'culturally illiterate,' whose social class, race, or gender renders their own experiences and stories as too unimportant to be worthy of investigation” (p. 181). McLaren's statement describes the school experience I had in the United States, where my Mong culture and language was not recognized in the classroom. I began school in the US in adolescence, without any prior educational experience with European culture. I had emigrated from Southeast Asia with my mother and siblings as a result of the US, CIA Secret War in Laos. I had a negative experience in school making a connection from my culture to the cultural literacy in which my teachers taught me. I felt like some of the teachers were culturally blind and indifferent. They remained ignorant of my culture and perhaps unwillingly attempted to replace my culture with theirs. Cummins (1996) notes that the teachers who see their role as replacing or subtracting students' primary language and culture results in that assimilation of students to the dominant culture.

Furthermore, I witnessed in the American public school that literacy functioned to replace many important values of my culture and language. For example, at home I was having a difficult time understanding what my mother was saying and unable to do of the simple tasks she requests. I felt like I was completely disconnected from my cultural worldview through the type of literacy education I received in the public school. Powell (1999) states, "For literacy to be transformative, oral and written language must have personal relevancy for students. They must be able to see themselves in written and oral texts; they must believe that language has meaning for them" (p. 100). Through my elementary, junior high and high school education 
I discovered that the literature and history taught traditional Western stories and cultural values. The literacy I studied tended to explain the important values of written culture, of Western stories, but not the oral culture and Eastern narratives, the culture with which I was most familiar. Freire and Macedo (1987) describe oral literacy in the United States by giving an example that, "Literacy's oral dimension is important even if it takes in a culture like that of the United States, whose memory is preponderantly written, not oral like that of Africa” (p. 50). Dyc (1994) states if Native American cultures and traditions are taught, they become a threat and create conflict with a school system based on Western European ideologies and values.

Dyc's research describes the problem that parents and students who have strong ties with an oral culture currently struggle with in this society. A few years ago, I did a study with the Mong students in northern California and I found that they used their written literacy skills they learned in schools to challenge their oral literacy values (Thao, 2003). My research revealed that intensive literacy encouraged work of the school Mong children to lose interest in their oral culture. Similarly, McLaughlin (1994) reported that critical literacy caused tremendous pain and suffering for Navajo and other American Indian children. These children were put into English only boarding schools as early as age seven, without speaking a word in English. These children were isolated from their culture, stories, language, family and community. Currently many schools continue to suppress the Indian's culture and their indigenous stories. Example of Navajo historical, the long walk of Pocahontas story claimed by literature and Disney, vilified Indians except Pocahontas who was a "good Indian" and a heroine of EuroAmericans. Chief Roy Crazy Horse (1998) explained the truth about Pocahontas, "was a nickname meaning 'the naughty one' or 'spoiled child,' her real name was Matoaka” (p. 129). Pocahontas actually had a sad ending: "In 1612 at the age of 17, Pocahontas was treacherously taken prisoner by the English while she was on a social visit and was held hostage at Jamestown for over a year" (Chief Roy Crazy Horse, 1998: p. 130). These facts about Pocahontas were not revealed to our children in schools. Bicultural and bilingual students continue to receive a curriculum in the public school, which hides their culture, similar to the early days for Native American students.

My own junior high and high school literacy experience was terrible. I studied through the meritocry system that perpetuates the cultural capital of white middle class European-American. I did not remember studying anything about multicultural literature until I was in graduate school. The literature I read in high school like, "Romeo and Juliet, Scarlet Letter, etc." were boring. I did not find these stories to be interesting. I could find no connection with the story. I read a lot of William Shakespeare and Mark Twain's work, but they wrote about the culture of Europeans. I knew nothing about the culture of European Americans but I had no choice. I had to force myself to read this literature in order to earn the grade I wanted in class.

Literacy gives people the ability to use written language effectively, both to glean meaning from text and to produce one's own text (Ada \& Campoy, 1998). However, most literacy found in United States public schools educates bicultural and bilingual students not to discover the true meaning about themselves but mostly about others. It is an educational system educating bicultural and bilingual students about Euro-Americans' meritocracy and their superiority. Schools should provide a relevant literacy curriculum to bridge the gap for bicultural and bilingual students to understand cross-culture values as well as make sense of cultural differences. Goodman, Goodman and Flores (1984) concluded their research on literacy and biliteracy issues for reading and writing in bilingual education:

If school is relevant, if its curriculum and goals are consistent with the functional needs of the pupils, if it accepts their language and culture and builds on it, then children will respond to school and grow. But if the school is irrelevant and insensitive, the pupils will only make whatever minimal accommodations they can to its demands (p. 41).

Ada and Campoy (1999) argue, "If the curriculum and school practices and discussions do not incorporate the knowledge of their families and the richness of their home culture, students' own self-image is threatened” (p. 3). A study by Seda, Liguori and Seda (1999) supports that if teachers implement curriculum engaging the English as a Second Language (ESL) students' prior knowledge, then ESL students' critical thinking skills in readings and writings are improved. This is an excellent tool. Cummins (1996) states, "Prior knowledge represents one central aspect of what students bring to the learning situation that makes input more context-embedded and comprehensible” (p. 76).

Jiménez and Gersten (1999) did a study of two Latina/o teachers in Southern California, who were improving literacy instruction in the classroom. They found that these two teachers utilized a variety of literacy experiences to help their students with literacy. They role-played, utilized cultural response literacy, and modeled every lesson they intended to teach for their students. These teachers devoted lots of their time to the students and the students' cultures. This study concludes that teachers, "had successfully negotiated the educational system, maintained and nurtured their Latina/Latino identity, and were currently implementing classroom practices that include students’ language and culture” (p. 296). Cummins (1996) asserts that in order for culturally diverse students to be academically successful they must develop a sense of self identify through learning. Public school's literacy should foster bicultural and bilingual students to maintain a strong identity, to motivate them in reading and writing. For example, as a bicultural and bilingual student, I found it is less difficult for me to write a paper or read a story connected to my cultural reality than to write or read a topic about a cultural reality I am not familiar with. I believe this is true for many non-European students in public schools.

\section{Literacy Programs Is a Cultural Invasion}

Literacy not only creates problems in the school, but also generates major issues at home for bicultural and bilingual students. The cultural literacy in the public school becomes a threatening force and a cultural invasion at most bicultural and bilingual homes. Often bicultural and bilingual students directly apply what they learn in school to their everyday home life. For example, the Mong bicultural and bilingual students tend to replace their parents' culture and language with the literacy knowledge and skills of public school (Thao, 2003). Most bicultural and bilingual students refuse to speak, read and write in their heritage language because they need to continue to practice public school's literacy at home so they can do well in school. This leaves little room for bicultural and bilingual students to learn their own culture and language literacy at home. In this process the cultural literacy of the home is devalued. 
Because of the nature of public school literacy, bicultural and bilingual students place a high priority on the school culture and not on their home culture. Those students who are willing to make this adjustment will do well in school, but not do well in socializing with their home culture. Those students who have difficulty accepting this change will become failures in their school, but maintain a strong social cultural root. Devine (1994) asserts, "Minority-group members who adjust to the dominant definition of literacy may suffer severe social and personal displacement; those who are unwilling or unable to make this adjustment may well suffer literacy failure” (p. 234). The students who accept the school culture bring that culture to be their home culture and it overwhelms their home culture and creates conflict at home.

Due to a lack of home language and culture promoted in the public school setting bicultural and bilingual students often refused to speak their home language both at home and at school because they do not want to be identified as different at school. Ada and Campoy (1998) state that the Spanish-speaking students have to give up their Spanish to learn English to avoid being stigmatized and identified as an English as a second language learner. Bicultural and bilingual parents and students encounter this literacy crisis every day at school and at home. My study with the Mong children in northern California shows that the culture of school suddenly empowered the Mong students to challenge their parents' authority at home. Mong children give less respect to their parents and their cultural values because of what these Mong students gain from school. I concluded from this study that in order to empower the Mong students both the teachers and Mong parents need to work collaboratively with one another (Thao, 2003).

\section{Bicultural and Bilingual Literacy}

Literacy in the public school needs to have a connection with bicultural and bilingual students. Literacy programs need to bounce between the students' home culture and school culture. This way, reading and writing materials would not be a threat to the students. Delgado-Gaitan (1990) argues that literacy in and out school can be understood within the concept of cultural empowerment. Schools must provide literacy programs that allow bicultural and bilingual parents to teach their children their native culture and primary language, thus empowering them to have deeper knowledge of literacy, and of the reality of both cultures. When I was teaching in a public school, I had an after-school Mong literacy program to teach Mong history, stories, folktales, legends, reading and writing to Mong children (Thao, 2003). The Mong parents ran this Mong literacy program. It was a very effective program. Many Mong children did very well in school and in the after-school program. The program empowered Mong parents and children to learn Mong and English literacy together. Freire and Macedo (1987) argue that an effective literacy program should be based on the rationale that rooted in the students' culture as well as their native language. They stated, "The failure to base a literacy program on the native language means that oppositional forces can neutralize the efforts of educators and political leaders to achieve decolonization of mind” (p. 151).

Paratore, Melzi and Krol-Sinclair (1999) studied family literacy involving immigrant parents and children. They found that immigrant parents and children benefit greatly from family literacy programs. One literacy program they called the Inter- generational Literacy Project, supported many immigrant parents and students to engage in literacy. This literacy project also helped parents and students to make a smooth transition between home and school. Paratore, Melzi and Krol-Sinclair (1999) state that the purpose of family literacy is to share literacy activities and to share learning. For example, Parlier Unified School District in California successfully proved in three consecutive years that the district's Family English Literacy Program (FELP) helps the Spanish-speaking students to improve their abilities in reading, speaking and listening (BEOutreach, 1992). The program opens its door to the parents to facilitate and assist their children's education using Spanish literature and story telling. BEOutreach (1992) concluded this study by saying that teaching family literacy brings meaningful literacy to the Spanish-speaking students and parents.

Literacy programs in the public schools need to be a two-way learning process so the programs can help bicultural and bilingual students maintain their native language and culture. Programs in which students learn to accommodate others' cultures and languages are most effective. The Parajo Valley Family Literacy Project in Watsonville, California was an excellent model (Ada, 1988; Cummins, 1996). This family literacy project had a tremendous impact on the school district and the Hispanic community. Most families were migrant farm workers. This project created an open space and welcoming environment in the school for Hispanic parents to be part of their children's literacy education. The children of the Hispanic families that participated in the project made a big improvement in their literacy skills and stayed in school (Ada, 1988; Delgado-Gaitan, 1990, 1994; Cummins, 1996; BEOutreach, 1992).

\section{Conclusion}

Literacy crises are rising in bicultural and bilingual students' education in public schools. Today, we have a large number of bicultural and bilingual students who have dropped out of school, have become involved in gang activities, do not completed high school, and who are working for minimum wage jobs because of literacy issues. Many students cannot read and write at their grade level. These students are having trouble meeting the standard requirements for graduation. It is time for public school to consider infusing bicultural literacy as part of the literacy program. This way, bicultural and bilingual students will be learning material that makes sense to them and they will be motivated to study, so they can graduate from high school, go on to college, and obtain a better pay job.

Literature can motivate bicultural and bilingual students in reading and writing. If a public school does not have appropriate literature to teach to bicultural and bilingual students, then literacy is no longer an interesting subject for students. Therefore, bicultural and bilingual students will continue to feel that schools do not prepare them to be a member of mainstream society. Often, public school does not meet the needs of bicultural and bilingual students, to help them maintain the balance between their home and school cultures. The bicultural and bilingual students mostly will be brain-washed to think that the Euro-American cultures and traditions have the most values. They will no longer know their own cultures, languages, and histories. Most bicultural and bilingual students no longer feel they have solid and respected identity. Their identity was lost, ignored or taken away from them during the time they went through school in our public educational system. Literacy 
should be the foundation to help bilingual and bicultural students to have a strong relationship between home and school culture values.

Public school's literacy programs need to include students' native languages and cultures. This way we can have effective literacy programs to teach bicultural and bilingual students to become literate. Jennings and Purves (1991) defined literacy as a "student's ability to read and understand both classical and modern literature, and to be articulate and sophisticated in written expression. Literacy is a survival skill in a complex technological society-it is the ability to read and write functionally in order to participate successfully in everyday life (on the job, at home, and in leisure activities)” (p. 143). Giroux (1988) states, "To be literate is not to be free; it is to be present and active in the struggle for reclaiming one's voice, history, and future" (p. 155). This is very true for me because it is the first step for bicultural and bilingual students to have the right tools to make changes in this society and create an identity sensitive to changes demanded by acculturations.

United States public school literacy programs need to empower bicultural and bilingual students to read, write and think critically in their culture and in other cultures. Literacy must become part of bicultural and bilingual students' reality. Teachers need to understand the implications of literacy programs that make a connection to the student's language and culture reality in their classroom. They must commit to work with the languages and cultural of the students, not against them in order for students to be open to learning anything. To discredit a student's language and culture means to discredit the student. Zanger (1994) states, "Student failure may be seen as a failure of the social system to provide linguistic-minority students with the appropriate social interactions necessary for literacy development” (p. 172).

Therefore, I urge that teachers, as part of the educational institution, must advocate for multicultural and multilingual literature as part of the public school's literacy culture. In order for bicultural and bilingual students to succeed on high-stakes tests that are demanded by the No Child Left Behind law, the pedagogical content of literacy must acknowledge these students and their culture. Public school literacy that focuses on students' heritage makes sense in their learning and this will raise student achievement on state-mandated reading and writing tests. Incorporate multicultural and multilingual literacy in public school to prepare our students for a growing and diverse American society.

\section{REFERENCES}

Ada, A. F. (1988). The Pajaro Valley experience: Working with Spanish-speaking parents and students to develop children's reading and writing skills in the home through the use of children's literature. In T. Skutnabb-Kangas, \& J. Cummins (Eds.), Minority education: From shame to struggle (pp. 224-238). Philadelphia: Multilingual Matters.

Ada, A. F., \& Campoy, I. F. (1998). Comprehensive language arts. San Francisco, CA: Del So Publishing.

Ada, A. F., \& Campoy, I. F. (1999). Home school interaction with cultural or language diverse families. San Francisco, CA: Del So Publishing.

BEOutreach (1992). FELP Project in the Parlier Unified School District promotes literacy through Spanish. Sacramento, CA: Bilingual Education Office.

Chief Roy Crazy Horse (1998). Pocahontas: The reality. In E. Lee, D.
Menart, \& M. Okazawa-Ray, (Eds.), Beyond heroes and holidays: A practical guide to $k-12$ anti-racist, multicultural education and staff development (pp. 129-130). Washington, DC: Network of Educators on the Americas.

Cummins, J. (1996). Negotiating identities: Education for empowerment in diversesociety. Ontario, CA: California Association for Bilingual Education.

Cadiero-Kaplan, K. (2004). The literacy curriculum \& bilingual education: a critical examination. New York: Peter Lang.

Darder, A. (1991). Cultural and power in the classroom: A critical foundation for bicultural education. Westport, CT: Bergin \& Garvey

Delgado-Gaitan, C. (1990). Literacy for empowerment. New York: The Falmer Press.

Delgado-Gaitan, C. (1994). Sociocultural change through literacy: Toward the empowerment of families. In B. M. Ferdman, R. M. Weber, \& A. G. Ramírez (Eds.), Literacy across languages and cultures (pp. 143-169). New York: State University of New York Press.

Delpit, L., \& Kilgour Dowdy, J. (2002). (Eds). The skin that we speak. New York: The New Press.

Devine, J. (1994). Literacy and social power. In B. M. Ferdman, R. M. Weber, \& A. G. Ramírez (Eds.). Literacy across languages and cultures (pp. 221-237). New York: State University of New York Press.

Dyc, G. (1994). The use of native language models in the development of critical literacy. American Indian Culture and Research Journal, 18, 211-233.

Freire, P., \& Macedo, D. (1987). Literacy: Reading the word and the world. Westport, CT: Bergin \& Garvey.

Giroux, H. A. (1988). Teachers as intellectuals: Toward a critical pedagogy of learning. South Hadley, Massachusetts: Bergin \& Garvey Publishers, Inc.

Goodman, K., Goodman, Y., \& Flores, B. (1978). Reading in the bilingual classroom: Literacy and biliteracy. Rosslyn, VA: InterAmerica Research Associates, Inc.

Jennings, E. M., \& Purves, A. C. (1991). Literate systems and individual lives: Perspectives on literacy and schooling. Albany, NY: University of New York Press.

Jiménez, R. T., \& Gersten, R. (1999). Lessons and dilemmas derived from the Literacy instruction of two Latina/o teachers. American Educational Research Journal, 36, 265-298.

Macedo, D. (1994). Literacies of power: What-Americans are not allowed to know. Boulder, CO: Westview Press, Inc.

McLaren, P. (1998). Life in schools: An introduction to critical pedagogy in the foundation of education. Menlo Park, CA: Addison Wesley Longman, Inc.

McLaughlin, D. (1994, Spring). Critical literacy for Navajo and other American Indian Leaners. Journal of American Indian Education, 33, 47-60

Olsen, L. (1997). Made in America: Immigrant students in our public schools. New York: The New Press.

Paratore, J. R., Melzi, G., \& Krol-Sinclair, B. (1999). What should we expect of family literacy: Experiences of Latino children whose parents participate in an Intergenerational literacy project. Chicago, IL: National Reading Conference.

Powell, R. (1999). Literacy as a moral imperative: Facing the challenges of a pluralistic society. New York: Rowman \& Littlefield Publishers, Inc.

Seda, M. M., Liguori, O. Z., \& Seda, C. M. (1999, Autumn). Bridging literacy and social studies: Engaging prior knowledge through children's book. TESOL, 8, 34-40.

Spring, J. (2004). Deculturalization and the struggle for equity. New York: McGraw Hill

Thao, Y. J. (2003). Empowering Mong students: Home and school factors. The Urban Review, 35, 25-42. doi:10.1023/A:1022675022518

US Department of Education (2004). No child left behind: A toolkit for teachers. Jessup, MD: Education Publications Center.

Zanger, V. V. (1994). "Not joined in”: The social context of English literacy development for Hispanic youth. In B. M. Ferdman, R. M. Weber, \& A. G. Ramírez (Eds.), Literacy across languages and cultures (pp. 171-198). New York: State University of New York Press. 